\title{
Internationalism, Patriotism, Dictatorship and Democracy: The Czechoslovak Communist Party and the Exercise of Power, 1945-1968
}

\author{
Muriel BLAIVE
}

Seldom has the presumed tension between internationalism and patriotism been given so much academic coverage as in the Czechoslovak case. From its very birth in 1921 until the crushing of the Prague Spring by the Warsaw Pact tanks in 1968, from the expulsion of the Social Democratic opponents in the 1920s to the «Czechoslovak path to socialism» between 1945 and 1948, from the «bolshevization» in 1929 to the alleged «cruellest terror of all popular democracies put together» in the beginning of the 1950s, from the absence of 1956 to the brilliance of the Prague Spring, the Czechoslovak Communist Party (KSČ) has been considered special, indeed very special. The Czechoslovak case is described as being unique in communist Eastern Europe.

What is the crux of this specificity? The KSC is said to have suffered from a particular kind of disease called the «democratic spirit», which impregnated Czech society so thoroughly from 1918 onwards that it supposedly didn't spare the Czechoslovak section of the Internationale.

A communist party impregnated by a democratic spirit? This paper will first of all carefully review this argument in its different chronological versions, ranging from the interwar to 1968; it will then argue that the «democratic argument» has much rather served to avoid questioning the local responsibilities in the terror regime of the 1950s; and finally, to emphasize this point, it will concentrate on the KSČ's policy in several concrete cases during the 1950s and argue that facts simply don't match with this «democratic theory».

As will come out in the course of this article, the internationalism/patriotism dichotomy reflects the fate of the European integration process only in a very twisted way. The European integration in the West can be seen as a successful internationalist project, slowly attempting to overcome patriotic - actually, more often than not, chauvinistic - traits. In the East, the idea of internal cohesion promoted by the communist elites was negatively perceived by the population as it mostly served to disguise exploitation by the Soviet Union; the concept of European integration as it was thought of in the West was largely repressed. The Cold War reinforced the East-West divide and it is only when it came to an end that a redefinition of the European project including both the «East» and the «West»the famous «return to Europe» - could begin. ${ }^{1}$

This article points to the fact that the Eastern «cohesion» which preceded it was rather questionable, not because Czechoslovakia was democratic and the other

1. See H. ARMBRUSTER, C. ROLLO, U.H. MEINHOF, Imagining Europe Everyday Narratives in European Border Communities, in: Journal of Ethnic and Migration Studies, 5(2003). 
countries were not - what «Czech» historiography was so intent on proving - but on the contrary because Czechoslovakia embraced communism with a degree of sincerity unequalled elsewhere, with the possible exception of the former GDR. It also shows between the lines that almost anything is possible if the populations can be mobilized for a project whose values they share - both in the case of Czechoslovakia in 1945 and of the Czech Republic and Slovakia in 2004.

\section{Introduction to the «democratic spirit» of the Czech nation}

In the Czechoslovak historiography, or rather in the Czech one, ${ }^{2}$ the tension between internationalism and patriotism has been largely equated with the antinomy dictatorship/democracy. The dichotomy East/West was never very far from most of the authors' mind either. Contrary to the claimed «uniqueness» of the Czech case, this issue is in fact common in the wider context as practically each Central European country is convinced to have been the last bastion of civilization before the «barbarian» East. After 1948, «East» became synonymous for the end of Europe, lack of civilization, dictatorship, Moscow's orders and therefore of internationalism; «West» represented culture, development, democracy, in other words patriotism. ${ }^{3}$

This vision fitted in a framework where Czechoslovakia had largely celebrated itself for being the only democracy in Central Europe - later referred to as the «East bloc.» Indeed, in contrast to interwar Poland and Hungary, or to Yugoslavia, Romania and Bulgaria, not to mention Germany and Austria, a true democracy was established between 1918 and 1938 under the patronage of president Tomáš Garrigue Masaryk and of his successor Edvard Beneš. Free elections were guaranteed, as were freedoms of speech, of the press, of meeting, of movement, etc. A significant measure of minority rights was granted. ${ }^{4}$

The problem is that this Czechoslovak democratic spirit has been generally over-interpreted, both in the interwar period and after the Second World War, 5 especially in contrast to Poland and Hungary. It is true that the latter did not enjoy the same degree of freedom in the interwar period, for instance, but the intellectual life was nevertheless flourishing in those two countries, a fact easily forgotten on the Czech side. Instead, a vast historiographical current - which might seem

2. Unfortunately Slovakia didn't have much of a word to say concerning the running of the country, neither in the 1920s and 1930s - which led to the well-known Slovak fascist state during the Second World War -, nor in the 1950s and 1960s. Czechoslovakia was turned into a federation only on $1^{\text {st } J a n u a r y ~ 1969 . ~ T h e ~ v a s t ~ m a j o r i t y ~ o f ~ a c a d e m i c ~ w o r k s ~ d e a l i n g ~ w i t h ~ « C z e c h o s l o v a k i a » ~ a c t u a l l y ~}$ deal almost exclusively with the Czech lands.

3. For an elaborate and elegant version of this trend, see for instance M. KUNDERA, Un Occident kidnappé ou la tragédie de l'Europe centrale, in: Le Débat, November 1983, pp.3-21.

4. It was a kind of paternalistic democracy which would also describe the French third- or even fourth Republic, where criticism of De Gaulle was tolerated but where the state would keep a significant amount of control on national broadcasting medias. 
incredibly outdated today but which is practically the only one existing to date as it has hardly been renewed since the 1980s -, has devoted itself to the study of the famed Bohemian democratic heritage and of its legacy onto the Communist party of Czechoslovakia and onto its militants. We will review the different chronological stages of this argument, ranging from the First Republic to the 1945-1948 period, to the 1950s in general, 1956 in particular, and of course to the Prague Spring.

\section{The «democratic spirit» of the KSČ from the interwar period to 1968}

To avoid confusion, we will first of all review the dominant «democratic narrative» of the Czech nation and of Czech communism in twelve different variations, and then we will go back to the arguments one at a time. ${ }^{6}$

At the origin of Czech democracy, thus, was the First Republic. For numerous political scientists and historians, mainly American, Canadian and Czech, ${ }^{7}$ the KSC's history placed it in cantilever between the democratic atmosphere in which it had been born and its allegiance to Moscow. It was said to have found itself in an ambiguous position after 1948 since it was both a dictatorial party in power and the heir of the First Republic democratic institutions, in which it had taken part. ${ }^{8}$ In other words, it would have been submitted to an internal conflict between its own democratic tendencies, nourished by Masaryk's regime, and its authoritarian tendencies, which eventually led it to seize power through force in 1948.

In the relevant literature, the KSČ has been understood to work on a different basis than the other Komintern members already before World War II. In the 1930s, the Czech militants were allegedly reluctant not only to sacrifice their life for revolution's sake but also their spare evenings. ${ }^{9}$ Apart from a few muscled speeches

5. And even, one might add, after 1989: the general notion that the Czechs are the «best pupils of the class» led to an optimistic (if not outright arrogant) self-analysis of the Czech elites concerning their country's ability to step into the EU - specifically to be the first Central European country to do so. See J. KARLAS, P. KRATOCHVÍL, Czechoslovakialthe Czech Republic and European Integration: During and After the Cold War, in: Journal of European Integration History, 2(2004), p.37.

6. To underline this narrative's predominance in the Czechoslovak literature, we will refer to as many authors as possible in this short article. These references already abundantly show the very diverse ideological and chronological provenience of these concordant arguments; however, for a more detailed review and a hopefully convincing demonstration of this narrative's almost unanimous character, please refer to M. BLAIVE, Une déstalinisation manquée, Tchécoslovaquie 1956, Complexe, Bruxelles, 2005.

7. For a study of Czech intellectuals' influence on American politics and, by extension, on North-American academia on Czechoslovakia, see J. FAURE, L'ami américain. La Tchécoslovaquie, enjeu de la diplomatie américaine 1943-1968, Tallandier, Paris, 2004.

8. B.W. JANCAR, Czechoslovakia and the Absolute Monopoly of Power, Praeger, New-York, 1971, p. 50.

9. E. TABORSKY, Communism in Czechoslovakia 1948-1960, Princeton University Press, Princeton, 1961, p.7. 
on Klement Gottwald's part, we are told that the KSČ did not threaten the democratic institutions and was well integrated. In sum, it had lost its revolutionary character, at least among the rank-and-file. ${ }^{10}$

Is that to say that Czechoslovak communism, which had deep roots into the working class, suffered more than others from the conflict between its national traditions and the policy imposed by the Soviets? This would be all the easier to believe that the Komintern leaders themselves pointed their finger at the KSC members with this 1928 open letter: «It is precisely because the KSC suffers from a significant social-democratic heritage and has not forged itself in revolutionary fights that it must find its own Bolshevik line», it said. ${ }^{11}$

In 1945, on the other hand, the KSČ was in a good position to convince the population that a «specific Czechoslovak path to socialism» could succeed. Its popularity portended that the new type of Communist regime it was promising was achievable. Yet, as soon as it found itself in charge of the state in 1948, what Barbara Wolfe Jancar has named a «logic of absolute monopoly», centred in the USSR, allegedly forced it to adopt the «same position» as Gottwald in the 1930s, i.e. to Stalinize the party (and now the country). ${ }^{12}$ Supposedly, it was not easy. Gottwald is said to have resisted a long time before surrendering and accepting a total sovietization of the political institutions, a resistance which was understood to be the consequence of the «links, partly conscious and partly subconscious, with Western traditions which have left an indelible mark on Czechoslovak communism». ${ }^{13}$ In other words, the communists had to put aside the «Czechoslovak experience» of democratic socialism and to rely on Moscow to be able to remain in power.

This situation is said to have resulted in the disaster of repression: «Rigidity and an orthodoxy more conservative than that of the Soviet party was Gottwald's response to the KSČ's new power position». ${ }^{14}$ In fact, the Czechoslovak Communist party members allegedly suffered from a «split personality», torn as they were between their loyalty for Moscow and for their own country. ${ }^{15}$ In the concrete case of 1956, for example, the Czechoslovak delay in destalinizing is explained in literature by the «idiosyncratic framework of Czechoslovak political

10. Idem., p. 7.

11. J. RUPNIK, Histoire du parti communiste tchécoslovaque, Presses de la FNSP, Paris, 1981, p.73.

12. B.W. JANCAR, op.cit., p.55. The fact that Western historians based themselves on (or, in Taborsky and Duchacek's case, even preceded) reform communist historians or witnesses, such as Karel Kaplan, Evžen Löbl or Artur London without ever questioning their ideological background shows (1) how political the history of popular democracies during the Cold War was, (2) what legitimacy Prague Spring intellectuals had attained in the West, (3) how pregnant the thesis of the «Czech democratic spirit» was, since it bound together practically all historiographical currents, however diverse they may have been. For a study of the importance of this «democratic argument». See M. BLAIVE, La démocratie pour les Tchèques: une légitimité politique et une composante identitaire, in: Revue d'études comparatives Est-Ouest, 1(2003), pp.59-82.

13. E. TABORSKY, op.cit., p.603.

14. B.W. JANCAR, op.cit., p.55.

15. Ibid., p.52. 
culture», which accounts for the leaders' «apprehensions about the possible consequences of a major policy revision.» In other words, «Among the parties in control, only the KSC was aware of the power of public opinion». ${ }^{16}$ The democratic traditions, we read, also refrained people from expressing their discontentment. The «sophisticated sobriety of the opponents, reared in the tradition of democracy and its non-violent methods of action» allegedly accounts for the lack of resistance of the Czechoslovak population. ${ }^{17}$ Face to face with an anti-democratic regime, democratically raised citizens, deprived of their only weapon, the right to vote, felt powerless.

As for the party members, they are said to have felt equally democratic. The news of Nikita Khrushchev's secret speech caused «a new and surprisingly vigorous inner-party democracy». ${ }^{18}$ The party was supposedly upside-down. The Central Committee was said to be flooded with demands for an extraordinary party congress. ${ }^{19}$ Even though such a party congress actually never took place, some of the authors' enthusiasm was revived by the 1968 events. The rehabilitation law passed in that year, for instance, was welcomed:

«The passage of the law on rehabilitation was a humane step, rare in history, and
unique in the communist world, to restore justice to the victims of illegalities of an
entire historical period and to supplement the limited and inadequate measures of
correction taken in the sixties. It was the first occasion in a communist country in
which an action of such vast scope, embracing even discrimination and persecution
by administrative agencies, was to be undertaken in accordance with strictly legal
procedures». ${ }^{20}$

Finally, nowhere more than in the gloomy area of the numbers of victims to the Communist terror regime the «democratic argument» is more emphasized. A vast majority of authors consider that Czechoslovakia suffered an unprecedented level of terror, in fact «higher than in all the other popular democracies put together». ${ }^{21}$ Why? Precisely, so the argument goes, because Czechoslovakia had strong democratic traditions, in and outside of its communist party: to destroy them, one needed a much higher level of terror than elsewhere. Hence the «especially ruthless character of Stalinism in the 1950s [which] was, in a sense, proportional to the

16. Z. SUDA, Zealots and Rebels. A History of the Communist Party of Czechoslovakia, The Hoover Institution Press, Stanford, 1980, p.258.

17. Ivo DUCHACEK, «A 'Loyal' Satellite: The Case of Czechoslovakia», in Henry L. Roberts (ed), The Satellites in Eastern Europe, Philadelphia, AAPPS, 1958, p.115.

18. E. TABORSKY, op.cit., p.77.

19. J. PELIKÁN, S' ils me tuent ..., Grasset, Paris, 1975, p.112.

20. G. SKILLING, Czechoslovakia's Interrupted Revolution, Princeton University Press, Princeton, 1976, p.409.

21. K. KAPLAN, Zamyšlení nad politickými procesy, in: Nová mysl, 7(1968), p.915. This argument was taken over by nearly ever author every writing on Czechoslovakia in the 1950s. See for instance J. RUPNIK, op.cit., p.15 and p.229; A. KRATOCHVIL, Žaluji I. Stalinská justice v Československu (I Accuse), Dolmen, Prague, 1990, p.5; O. ULČ, Politics in Czechoslovakia, San Fransisco; G. FEIWEL, New Economic Patterns in Czechoslovakia, Praeger, New-York, 1968, p.139; J. PELIKÁN, op.cit., p.82; B.W. JANCAR, op.cit., p.100, Z. HEJZLAR, Praha ve stínu Stalina a Brežněva (Prague in Stalin's and Brejnev's Shadow), Práce, Prague, 1991, p.34; etc. 
democratic traditions it had to destroy». ${ }^{22}$ In other words, both the Western historians, the Czech democrats in exile and the former reform communists agreed after 1968 that the Czechoslovak terror had been much higher than in other countries because the democratic traditions had to be destroyed (for the democrats, inside society, for the reform communists, inside the communist party).

Let us now go back and re-examine each argument in turn.

\section{A dispassionate look at Czechoslovak communist history}

These arguments are all marked by an understandable, but often unreasonable, sympathy for Czechoslovakia's fate. Time and the ideological appeasement of the post-Cold War period now permit a more dispassionate approach. In fact, simple logic suffices to put most of the arguments back into perspective. Why, for instance, would the KSČ «suffer» once it had attained power? It was striving to do so and it did; this friendly presentation of the KSČ is simply naïve. Let us for instance call back to memory the testimony of a direct witness, Ota Hromádko, who describes, as an early Communist militant, his activities under the First Republic; reading through his account, one will be convinced not only that he dedicated more than a spare evening to the Revolution, ${ }^{23}$ but also that he and his comrades had no qualms about fulfilling their goal: reaching power.

More importantly, a revolutionary wave of violence inspired by the Marxist left swept Czechoslovakia in 1919-1921, notably with a general strike in December, 1920 and an insurrectional situation in Kladno and Most. ${ }^{24}$ The middle-class thought a coup was under way and the strike was bloodily crushed. At least 13 people were killed. ${ }^{25}$ In Slovakia, a Republic of Councils was established (July 1919) and constituted the first attempt to export the Bolshevik revolution out of Russia. ${ }^{26}$ The troubles started again after the 1929 crisis and were again stirred by the Communist party. ${ }^{27}$ And the presentation of the KSC $\check{\text { as a }}$ «good child of the Republic» is gravely undermined by these few sentences pronounced by Gottwald after he was elected to Parliament in 1929:

22. See G. SKILLING, op.cit., p.825. See as well F. EIDLIN, The Two Faces of Czechoslovak Communism, in: East-Central Europe, (1-2)1983, p.189; F. AUGUST, D. REES, Red Star Over Prague, Sherwood Press, London, 1984, p.XVII; Z. HEJZLAR, op.cit., p.34; J. PELIKÁN, op.cit., pp.82-83.

23. O. HROMÁDKO, Jak se kalila voda (How the Water Got Troubled), Index, Cologne, 1982, pp.9-95.

24. J. RUPNIK, op.cit., p.49.

25. V.S. MAMATEY, Le développement de la démocratie tchécoslovaque, in: V. MAMATEY, R. LUŽA (eds), La république tchécoslovaque 1918-1948, Librairie du regard, Paris, 1987, pp.96-97.

26. J. RUPNIK, op.cit., pp.44-45.

27. V.S. MAMATEY, op.cit., p.131. 
«We are the party of the Czechoslovak proletariat and our general staff is in Moscow.

We go to Moscow to learn from the Russian Bolsheviks how to twist your necks.

And as you know, the Russian Bolsheviks are masters at that». ${ }^{28}$

As for the lack of Czechoslovak destalinization, the alleged blindness of the Polish and Hungarian Communists to the power of public opinion between 1953 and 1956 also has to be contended. The existing interviews, for instance that of Edward Ochab's, ${ }^{29}$ show, on the contrary, that the leaders were very much aware of the risks incumbent to destalinization. They did it not because they were fools, but because there was a strong public demand for it which they did not feel politically able to stand up to.

The KSČ was all the less the only party aware of the power of public opinion as the Hungarian and Polish party's ground was not as secure. The Communist parties' policy is always more fluctuating when the public's pressure is mounting, as is shown by the detailed chronology of the period 1953-1956. ${ }^{30}$ All concessions on the leadership's part in Poland and Hungary (apart perhaps from the very first one, the nomination of Imre Nagy, in which the Soviets apparently played a major role) were the result of popular pressure. The fact that the KSC didn't make any concessions, or very little, is a proof not of its dogmatism but of the fact that there was no significant demand for such concessions. It should lead to wonder how come there was so little discontentment, not to reflect on the alleged «Stalinian wisdom» of the Czechoslovak leadership.

The Czechoslovak democratic tradition must not be disregarded but neither can it help to explain why people did nothing in 1956. Incidentally, those who did oppose the regime and ended up in jail or were killed are better reminders of the democratic traditions than those who remained almost or totally passive. That the population was aspiring to freedom and democracy is certainly true but it is not necessarily incompatible with a partial satisfaction on the socio-economic, and even patriotic, level. If the Czechoslovak population was not pro-communist, it didn't show any strong sign of anti-communism either, neither at that time nor later. $^{31}$

This is true as well of the Communist party members: as we have seen above, the party was said to be upside-down and flooded with demands for an extraordinary party congress in 1956 . In reality, only $0,5 \%$ of the party local organisations called for such a congress to take place. ${ }^{32}$

28. J. RUPNIK, op.cit., p.78.

29. See the chapter «Edward Ochab» in: T. TORAŃSKA, Oni. Stalin's Polish Puppets, Collins, London, 1987, p.48.

30. See this chronology in M. BLAIVE, Une déstalinisation manquée ..., op.cit., pp.224-253.

31. This could have been deduced already before 1989 but is becoming increasingly clear since the archives are being opened. See for instance this analysis of the State Security reports on the people's mood during the 1956 Hungarian revolution in M. BLAIVE, La police politique communiste en action: les Tchécoslovaques et la révolution hongroise de 1956, in: Revue d'histoire moderne et contemporaine, 2(April-June 2002), pp.176-202. There was little of a «revolutionary mood» among the Czechoslovaks. 
As far as the special role of Czechoslovakia in the terror policy is concerned, finally, it can be contested on two fronts. First of all, it is simply wrong. Since the opening of the archives in 1989, we know, even if only roughly, that Czechoslovak terror was not greater than in any other popular democracy and certainly not greater than in all the other countries put together ${ }^{33}$ (at least in statistical terms, one might argue that such a gruesome simplification doesn't leave any space to the victims' feelings, which are yet legitimate and commanding respect - in Czechoslovakia, too, but not only in Czechoslovakia). But even if we leave statistics aside, it would have been only logical to invoke the real level of support for the communist party inside a given country to explain a particular level of terror. If we take for instance Czechoslovakia and Hungary, the difference lies not in the presence or absence of democratic traditions but in the fact that the KSC pulled $38 \%$ of the votes in Czechoslovakia in 1946, becoming the leading political party of the country, ${ }^{34}$ whereas the Hungarian Communist party had pulled a few months earlier only $17 \%$ of the votes, which put it far behind the Smallholders' party which had gained a stunning $60 \%$. The Hungarian people, by clearly rejecting the communist option, obviously risked a lot more to be persecuted by a Communist party in power.

The Polish and the Hungarian examples - not even to mention Romania or Bulgaria - suffice to show that it is not the presence of democratic traditions which accounts for the depth of the repression. And if the Czechoslovak 1968 rehabilitation law was «unique», it is so only in its 14-year delay: the Hungarians and the Poles had proceeded to extensive rehabilitations already between 1954 and 1956. László Rajk and Wladysław Gomułka were both fully rehabilitated in 1956, whereas Rudolf Slánský never was reinstated in the KSČ, not even in 1968.

But let us now concentrate in greater detail around some of the above mentioned arguments, i.e. around the central question of internationalism vs. patriotism.

32. See A. NOVOTNÝ, Současná situace a úkoly strany (The current situation and the party's tasks), Nová mysl, Celostátní konference KSČ, June 1956, p.25.

33. See M. BLAIVE, Une déstalinisation manquéé ..., op.cit., pp.93-101.

34 . And secured the absolute majority $(55,75 \%)$ in the Czech lands together with its Social-Democratically. Counting the Socialist-National party, the socialist coalition reached an astonishing $79,41 \%$ of the Czech vote. 


\section{The KSČ policy}

\section{0s and 1930s}

What is important to keep in mind is that in the 1920s and 1930s, division was in the very nature of the Communist parties, insofar as it reflected the power struggle which took place in Moscow. In this respect, the KSČ is not specific in the least. Let us remember the history of the Hungarian Communist party at the turn of the 1930s with the confrontation between Gyorgy Lukács' «Blum Theses», Béla Szántó's «Robert Theses» and Gyula Alpári's theses taken over by József Révai. Just like in the KSČ's case, the Komintern sent an open letter to the Hungarian PC members. ${ }^{35}$

The history of the French Communist party at that time was very similar: some denounced the leadership's sectarism, were excluded, created a dissident party, while the said leadership was torn between the men in place, the trade-unionists and the Communist youth leadership. In an open letter sent on 7 December 1930 by the Komintern to all PCs, the French Communist party was denounced as one of the most faulty sections. In other words, the PCF was said to be «the worst pupil of the communist class». ${ }^{36}$

The title of «worst pupil of the communist class» would actually fit many of the Central European Communist parties by the end of the 1920s, insofar as the Komintern's grip on the parties' organisation and tactics was never easy to accept. But those who found it the hardest were undoubtedly those whose life was endangered by Moscow's dogmatism, because they already had to live in clandestinity under a right-wing dictatorship: from the beginning the Polish, Hungarian and Yugoslav parties, later on the German and Austrian ones. The first three were particularly attacked by the Komintern. ${ }^{37}$ The first two were even dissolved: the Hungarian apparently in $1936,{ }^{38}$ the Polish in $1938 .{ }^{39}$ The third one was able to make it only thanks to Josip Tito's personality but at the price of a zealed purge of its own ranks (the «split personality» issue undoubtedly applying

35. See A. KRIEGEL, S. COURTOIS, Eugen Fried, Le Seuil, Paris, 1997, p.97. See also M. MOLNÁR, De Béla Kun à János Kádár, Presses de la FNSP, Paris, 1987, pp.67-79.

36. Idem., pp.119-120.

37. See B. LAZITCH, Les partis communistes d'Europe 1919-1955, Les îles d'or, Paris, 1956, p.87.

38. See M. MOLNÁR, op.cit., p.82 and p.87.

39. See M.K. DZIEWANOWSKI, The Communist Party of Poland, Cambridge, Harvard University Press, 1976, p.150. 
here in full force).$^{40}$ In all three cases, their Central Committee members exiled in Moscow were exterminated. ${ }^{41}$

Yet one can not speak of an authentic «democratic heritage» when referring to Poland, Hungary or Yugoslavia. The divisions inside their Communist parties nevertheless existed and were even more exacerbated than in the Czech case. All of them had at least two antagonistic wings, which reflected the opposition between internationalism and patriotism.

\section{5-1948}

Doubts on Gottwald's will to plan and implement the monopoly of power in his country also have to be lifted. Gottwald had been politically educated in Moscow. He had ruthlessly stalinized the Czechoslovak Communist party in 1929 and earlier (see the Bubník case in 1925). ${ }^{42} \mathrm{He}$ had been one of the main organizers of the Komintern's VII ${ }^{\text {th }}$ Congress in 1935, spending one and a half years in Moscow for this purpose. He had been elected on the Komintern's political bureau along with personalities such as Georgi Dimitrov, Otto Pieck and Palmiro Togliatti. He had attended the trial of the «Trotskyist criminals» in $1937 .{ }^{43} \mathrm{He}$ had also spent the war in Moscow. There can be little doubt that he purposely drafted the after-war political institutions in the ambivalent spirit which would allow him to take power sooner or later - as was dictated by Stalin. ${ }^{44}$

What is certainly true, on the other hand, is that numerous European communist militants, at the bottom and even at the top, had faith, after the war, in the communist discourse; however, as Miklós Molnár remarks, this doesn't mean that one can speak of an authentic «democratic current» inside the Communist parties. ${ }^{45}$ The 1948 tactical change was dictated by Stalin, just like the conciliatory policy of 1945-1948 had been, and Gottwald followed suit, just like Mátyás Rákosi and Bolesław Bierut.

40. See A.B. ULAM, Titoism and the Cominform, Harvard University Press, Cambridge, 1952, p.20. For an eye-witness account, see M. DJILAS, Tito, mon ami, mon ennemi, Fayard, Paris, 1980, p.44.

41. See for instance B. LAZITCH, Stalin's Massacre of the Foreign Communist Leaders, in: M. DRACHKOVITCH, B. LAZITCH, The Comintern: Historical Highlights, Praeger, New-York, 1966, pp.139-174 and B. SOUVARINE, Comments on the Massacre, in: ibid., pp.175-183.

42. See J. RUPNIK, op.cit.

43. See F. NEČÁSEK, O Klementu Gottwaldovi. Náčrt životopisu (On Klement Gottwald. Sketch of a biography), SNPL, Prague, 1954, pp.37-41.

44. In the 1945 institutions, the decision making was taken away from experts and administrations and given to sole politicians. The unity of the state was replaced by the unity of the political will. From 1945 onwards, a criticism of the means through which the goal would be achieved was still possible; but a criticism of the goal itself was already rendered impossible. See V. CHALUPA, Rise and Development of a Totalitarian State, H.E. Steinfert Kneese N.V., Leiden, 1959, pp.80-81.

45. M. MOLNÁR, op.cit., p.195. 


\section{The 1950s}

It is too easy an explanation, on historian Karel Kaplan's model followed by most other historians, to blame solely the Soviets for everything which ever went wrong with Czechoslovak communism: Gottwald was allegedly a «good guy», the inventor of the genuine «Czechoslovak path to socialism», ${ }^{46}$ who was distracted from his «noble» task only by Stalin's blood thirst, a fact which caused him a great deal of pain and explains why he surrendered to alcoholism before and during the political trials. As for the trials, the reasoning was simplified in the following way:

«The domestic causes of the trials, according to Kaplan, lay in the political process itself [...] This political order, contrary to Czechoslovak tradition, was a product of Bolshevik experience and was imported into Czechoslovakia as an essential feature of the policy of modelling all aspects of life on the Soviet pattern». ${ }^{47}$

But this narrative does not account for the strong domestic support for such a terror policy, including on Gottwald's part. If only the Soviets are guilty, it does not really help to understand why Antonín Novotný, KSČ's first secretary after 1953, did so little to implement a real destalinization in 1956, both as a successor to the Stalinian leader Gottwald and as Moscow's follower after the $\mathrm{XX}^{\text {th }}$ Congress. Accordingly, the year 1956 in Czechoslovakia - which didn't bring any substantial implementation of the destalinization process, contrary to what happened in Poland and Hungary -, and more generally the whole period 1953-1965, is conveniently left out in most books dealing with post WWII Czechoslovak history. The terror level and the democratic traditions vaguely serve to mask the incongruency of a supposedly democratic-minded population and of a Communist party who both completely failed to take part in the liberalization campaign in 1956. Alexander Dubček then pops out of history seemingly out of nowhere in the second half of the 1960s and is said to have revived the national, patriotic, side of Czechoslovak communism, before being forced again by the «evil» Soviets (the «internationalists») to give up.

Yet again, Dubček's gradual surrender, the fact that he himself undid most of what he had done while he was still in power and that he remained in spite of everything a dedicated communist ${ }^{48}$ is rather left out, just like the astonishing isolation of the valorous dissidents in the 1970s and 1980s. Rather than wondering why the latter were at best a couple of thousand in Czechoslovakia as opposed to some 30,000 in Poland and Hungary, academic literature abroad has concentrated

46. «After 1945, the Czechoslovak Communists sought new ways of passing from the national and democractic revolution of the immediate post-war period to the socialist revolution. They envisaged the transition as peaceful and democratic, and in this they were absolutely serious. For a time it seemed that they even had Stalin's support; one recalls, for instance, an interview with British Labour MPs in which he mentioned the possibility of a peaceful transition from capitalism to socialism». See J. PELIKÁN (ed.), The Czechoslovak Political Trials, Macdonald, London, 1971, pp.15-16.

47. G. SKILLING, op.cit., pp.389-390.

48. For instance, he dutifully came back to Czechoslovakia after he was revoked from his ambassador's post in Turkey in 1970 even though he was certain to be demoted, if not sent outright to jail. 
on an in-depth analysis of their samizdat and tamizdat texts - indeed very inspiring on the intellectual level but enjoying a remarkably limited support among the population.

\section{Pressure from «under» and concessions from «above»}

It should be reminded that it was not Gottwald who invented the theory of the «national path to socialism», but Stalin. It was indeed during the visit of Labour MPs to Moscow in the summer of 1946 that the Soviet leader formulated it for the first time and it was only then that the Czechoslovak communists began to refer to it (see Gottwald's first speech on this theme dated 4 October 1946: «On our Czechoslovak road to socialism»). ${ }^{49}$ Jiři Pelikán gives the impression that Czechoslovak communism was a pioneer in this matter, but this is only due to the fact that he remains silent about the rest of the world communist movement: yet Gomułka ${ }^{50}$ Rákosi $^{51}$ and Maurice Thorez, ${ }^{52}$ or even Togliatti and Dimitrov, made similar references to a national specific path to socialism. Success of the said path in Czechoslovakia as opposed to Poland and Hungary is not the consequence of the Czech communists' democratic mind but of the inclination of the Czechoslovak population towards an egalitarian, strongly socialist, regime. The national consensus can hardly be better illustrated than by the fact that the communists

49. K. GOTTWALD, O naši československé cestě k socialismu, in: Spisy (Collected Works), XIII(1946-47), SNPL, Prague, 1957, pp.230-231.

50. W. GOMUŁKA, Przemówienie sekretarza generalnego KC PPR Tow. Wl. Gomułki, in: W. GOMUŁKA, J. CYRANKIEWICZ, Jednošcia silni - zwycieżymy. Przemówienia wyglosone na zebraniu aktywu warszawskiego PPR I PPS w dniu 30 listopadu 1946 (By Uniting Our Forces - We Will Win), Warsaw, 1946, p.25. In the chapter «We follow a Polish road, the road to popular democracy», Gomulka explains: «We have chosen our own path, a socialist path of development, which we have named the path of the Popular Democracy. Along this road and in our conditions, the dictatorship of the proletariat or even less of a party is neither an aim itself, nor a means to achieve it».

51. See M. RÁKOSI, A magyar demokráciáért (For the Hungarian Democracy), Szinka, Budapest, 1948, p.376. In the chapter «Forward to a popular democracy!», Rákosi explains: «The Communist parties have learned in the course of the last quarter of the century that there is no unique path leading to socialism but that there are as many paths as there are countries which build them through their own experiences».

52. See M. THOREZ, Déclaration au journal anglais 'The Times', in: CEuvres de Maurice Thorez, Livre cinquième, t.23 (Novembre 1946-Juin 1947), Ed. sociales, Paris, 1965, pp.14-15. In the chapter «One can envisage on the path to socialism other roads than the one followed by the Russian communists», Thorez claims: «The progress of democracy throughout the world, inspite of a few exceptions which confirm the rule, allow us to envisage on the path to socialism other roads than the one followed by the Russian communists. In any case, the road is necessarily different for every country. We have always thought and said that the French people, rich of a glorious tradition, would find its own path towards more democracy, progress and social justice». 
mainly propagated a «democratic socialism» between 1945 and 1948, while the democrats were advocating a «socialist democracy». ${ }^{53}$

Its failure in Poland and Hungary is not the consequence of a lack of democratic spirit on the communists' side but of the fierce opposition of the (essentially agricultural) population to anything resembling socialism. Communism gained a strong base in Czechoslovakia because the party succeeded in presenting itself as the embodiment of patriotism. It failed in Poland and Hungary at that time because it was perceived on the contrary as the symbol of something imposed from the outside, while other political forces better represented the patriotic feelings. And it finally regained partial success in those countries, for example with Gomułka in 1956, when the communists were somehow able to re-establish a connection between patriotism and communism.

\section{The domestic soldiers of repression}

It is not Stalin who signed Rudolf Slánský's and Milada Horáková's death sentences but Gottwald. As of today, the KSČ and its successor the KSČM have refused to condemn or even to express regrets over Horáková's fate (respected political leader of the First Republic and dedicated Democrat, also persecuted by the Nazis, she was hanged along with three other defendants after a Stalinist trial in 1950 for alleged anti-state activities). On 27 June 2005, on the occasion of the $55^{\text {th }}$ anniversary of her execution, KSČM's vice-president, Václav Exner, expressed the view on Czech Radio that Horáková had been indeed guilty of anti-state activities after 1948, activities which even today would be considered as collusion with a foreign state. ${ }^{54}$ Yet it is not Stalin anymore who puts these words into Comrade Exner's mouth.

It was certainly not Khrushchev who stopped Novotný from destalinizing, as it was him who had launched the destalinization and encouraged the other communist parties to follow suit. Even though Leonid Brejnev's guilt in crushing the Prague Spring is overwhelming, it is again Dubček who chose to do what he did: he did refuse to consider the Prague Spring a «counter-revolution», but out of a genuine and unshakable communist faith, not out of a democratic spirit; and it didn't stop him in his report to the November, 1968 plenum of the KSČ from defending the

53. Cf. these words by Hubert Ripka, the democratic minister for Trade in the post-war government: «We want to create a new social order, which means radical changes in the economic structure according to socialist principles. We are entertaining the constructive energy and the creative spirit of our people because we thus offer them the real hope that our political democracy, which has overall proven its worth during the First Republic, will be supported and strengthened by the economic and social democracy. [...] I am convinced that we will manage in a few years to build an efficient socialist democracy in Central Europe». Quoted in G. BEUER, New Czechoslovakia and her Historical Background, Lawrence \& Wishart, London, 1947, p.41. Beuer made this interview of Ripka in 1945 or 1946.

54. See A. DRDA, P. DUDEK, Kdo ve stínu čeká na moc. Čeští komunisté po listopadu 1989 (Look Who’s Hiding in the Dark. The Czech Communists after November, 1989), Paseka, Prague, 2006, p.11. 
necessity of «normalization» and criticizing the «negative features» of the post-January 1968 policy and the «anti-socialist forces» currently active. ${ }^{55}$ And finally the Czechoslovak communists were among the most reluctant to follow Mikhail Gorbachov; if it had been up to them, 1989 would never have occurred.

\section{Conclusion}

The antinomy between internationalism and patriotism has been instrumentalized in the Czechoslovak case to present a vision of good, patriotic local communists against bad, international (Soviet) communists and to exonerate the Czechoslovak communists of the worst of their mistakes.

A re-evaluation of Gottwald's historical role could be a first step. Unfortunately, Czech historians do not seem in a hurry to embark on this hazardous journey and the existing biographical notes remain at the level of a «personal drama» on Gottwald's part. ${ }^{56}$ They do not seem in a hurry either to re-evaluate in writing the fundamental myth of the Czechoslovak communist regime, e.g. that the level of terror was higher than in all the other democracies put together; therefore it keeps permeating most Western works on this period. ${ }^{57}$

And finally, they do not seem in a hurry to reinstate society, rather than political institutions and specifically the KSČ, at the heart of their analysis. The existing Czech historiography still favours the big events $(1948,1968,1989)$ or riskless topics like repression and opposition rather than questioning the involvement of Czech society in the communist regime. ${ }^{58}$ Yet it is not a coincidence if the Czech communists have still been polling $20 \%$ of the popular vote 15 years after the Velvet Revolution; it testifies to the long-term support basis for the communist regime built over the years. To gain a plausible explanation of this phenomenon, one will undoubtedly have to plunge into the historical depth of Czechoslovak communism. Until this comes into being, the dealing with the memory of communism under post-communism will remain rather abstract.

55. G. SKILLING, op.cit., p.815.

56. See for instance Českoslovenští a čeští prezidenti (Czech and Czechoslovak Presidents), CEP, Prague, 2003; J. PERNES, Takoví nám vládli (Those Who Ruled Us), Brána, Prague, 2003; V. KADLEC, Podivné konce naších prezidentů (The Strange End of Our Presidents), Kruh, Prague, 1991; K. KAPLAN, Gottwaldovi muži (Gottwald's Men), Paseka, Prague, 2004, etc.

57. See for instance a mild version in H. AGNEW, The Czechs and the Lands of the Bohemian Crown, Hoover Institution Press, Stanford, 2004. See also A. MARÈS, Histoire des Tchèques et des Slovaques, Perrin, Paris, 2005.

58. As often in similar cases, young, foreign historians are lending a hand in opening the debate on controversial topics: see for instance, on two very different chapters of Czech postwar history, B. FROMMER, National Cleansing. Retribution Against Nazi Collaborators in Postwar Czechoslovakia, Cambridge University Press, Cambridge, 2005 and P. BREN, Opposing the Opposition: Rethinking Fear and Apathy in Late Communist Czechoslovakia, presentation at the international workshop Authority and Expectations: A Social History of the Socialist Dictatorships in Central Europe, Charles University, Prague, June 21-22, 2007. 